\title{
Experiences of Falling Ill with Fibromyalgia: An Incursion into the Collective Imaginary of Women
}

\author{
Rodrigo Sanches Peres ${ }^{1}(1 D)$
}

\begin{abstract}
A psychoanalytic exploration of the collective imaginary of patients about a chronic condition can help health professionals to understand the experience of falling ill in its intersubjective aspect. This study aimed to investigate the collective imaginary about fibromyalgia in women affected by this syndrome. This is a qualitative study based on the psychoanalytic investigative method. Data were collected from 18 women through group interviews guided by the Drawing-Story with Theme Procedure. Data analysis followed technical movements defined by the oscillation from a receptive passivity to an active receptivity. Results showed that, after falling ill, the participants did not feel to be the same persons they were before or, in certain cases, no longer regard themselves as persons at all. It was also verified that delegitimation generates psychological suffering described by the participants as a kind of pain. Therefore, it is recommended to value relational technologies in health care offered by multidisciplinary teams to women with fibromyalgia
\end{abstract}

Keywords: fibromyalgia, collective imaginary, qualitative research, women - health and hygiene, psychoanalysis

\section{Vivências do Adoecer por Fibromialgia: Uma Incursão pelo Imaginário Coletivo de Mulheres}

\begin{abstract}
Resumo: Explorar psicanaliticamente o imaginário coletivo de pacientes sobre uma condição crônica pode auxiliar profissionais de saúde a compreender vivências do adoecer em sua vertente intersubjetiva. O presente estudo teve como objetivo investigar o imaginário coletivo sobre a fibromialgia em mulheres acometidas pela síndrome. Trata-se de um estudo qualitativo pautado pelo método investigativo psicanalítico. A coleta de dados foi realizada com 18 mulheres mediante entrevistas grupais norteadas pelo Procedimento de Desenhos-Estórias com Tema. A análise de dados foi orientada por movimentos técnicos baseados na oscilação de uma passividade receptiva a uma receptividade ativa. Verificou-se que, após o adoecimento, as participantes não se sentem mais as mesmas pessoas ou, em certos casos, não se veem mais como pessoas. Notou-se também que a deslegitimação gera um sofrimento psíquico descrito pelas participantes como uma modalidade de dor. Portanto, recomenda-se a valorização de tecnologias relacionais na assistência em saúde ofertada a mulheres com fibromialgia.
\end{abstract}

Palavras-chave: fibromialgia, imaginário coletivo, pesquisa qualitativa, mulheres - higiene e saúde, psicanálise

\section{Vivencias sobre el Enfermarse por Fibromialgia: Una Incursión en el Imaginario Colectivo de Mujeres}

\begin{abstract}
Resumen: Explorar psicoanalíticamente el imaginario colectivo de pacientes sobre una condición crónica puede ayudar a los profesionales de salud a comprender las vivencias sobre el enfermarse en su aspecto intersubjetivo. El presente estudio tuvo como objetivo investigar el imaginario colectivo sobre la fibromialgia en mujeres afectadas por el síndrome. Se trata de un estudio cualitativo basado en el método investigativo psicoanalítico. La recolección de datos se realizó con 18 mujeres a través de entrevistas grupales guiadas por el Procedimiento de Dibujos-Cuentos con Tema. El análisis de datos fue orientado por movimientos técnicos basados en la oscilación de una pasividad receptiva a una receptividad activa. Se observó que las participantes no se sentían las mismas personas después de enfermarse o, en ciertos casos, no se veían más como personas. También se encontró que la deslegitimación genera un sufrimiento psicológico descrito por las participantes como una forma de dolor. Por ello, se recomienda valorar las tecnologías relacionales en la asistencia sanitaria que ofrecen los equipos multidisciplinarios a mujeres con fibromialgia.
\end{abstract}

Palabras clave: fibromialgia, imaginario colectivo, investigación cualitativa, mujeres - higiene y salud, psicoanálisis

${ }^{1}$ Universidade Federal de Uberlândia, Uberlândia-MG, Brazil Support: CNPq (307100/2016-2) and FAPEMIG (PPM-00290-18).

Correspondence address: Rodrigo Sanches Peres. Universidade Federal de Uberlândia. Av. Pará, 1720, Uberlândia-MG, Brazil. CEP 38.408-100.

E-mail: rodrigosanchesperes@yahoo.com.br
In the universe of qualitative research, the term "experiences" refers essentially to the product of personal reflections on existential events, as clarified by Minayo (2012). However, the author warns that many components of the experiences come from the culture of the social group 
in which the individual is inserted. And it seems reasonable adding that the experiences are also directly influenced by psychic contents, conscious and non-conscious, so that they are not shaped only by rationally-established criteria. Turato (2013), in turn, emphasizes that it is around the experiences that human beings organize their lives, including their health care. Therefore, the understanding of experiences related to the health-disease process enabled by qualitative research is capable of generating useful scientific knowledge to improve the health professional-patient relationship and to increase treatments adherence.

The concept of collective imaginary, as originally conceived by the Brazilian psychoanalyst Tania Maria José Aiello-Vaisberg, has been used in qualitative research inspired by the contemporary psychoanalysis to designate the ideoaffective complex, predominantly non-conscious, on which the positioning of a social group regarding a certain phenomenon is based (Manna, Leite, \& Aiello-Vaisberg, 2018). Thus, the collective imaginary provides symbolic substrate to beliefs and emotions as well as attitudes and behaviors (GalloBelluzzo, Ferreira-Teixeira, \& Aiello-Vaisberg, 2017; Rosa, Lima, Miranda, \& Peres, 2021). It should also be noted that, according to the relational paradigm, which establishes that the unconscious does not figure as a purely intrapsychic instance, the psychoanalytic sense of collective imaginary assumes that its contours are outlined intersubjectively and situated in historical and cultural terms (Aiello-Vaisberg \& Ambrosio, 2013).

Therefore, the collective imaginary is sensitive to the external reality and concomitantly plays a relevant role in its daily (re)construction. In general, it also applies to the experiences, because they guide certain ways of acting (Minayo, 2012). Based on this, it is possible to propose that the psychoanalytic investigation of the collective imaginary about a phenomenon sheds light on the non-conscious basis of the experiences concerning it. And this assertion seems to be aimed mainly at complex existential events, such as falling ill with a chronic condition, for example. Thus, it is assumed that psychoanalytically exploring the collective imaginary of patients about a chronic condition can help health professionals to understand experiences of falling ill in its intersubjective aspect and, consequently, to value the human factor of clinical relationships that tends to raise the quality of health care, as Turato (2013) emphasized.

In line with Canesqui (2018), people with chronic conditions are usually stigmatized, because they suffer from something that, according to the canons of biomedical rationality, is often not recognized as a "true" health problem. In this scenario, still according to the author, delegitimization is recurrent. Fibromyalgia is a chronic, predominantly female condition in which this fact can be observed, as it has been target of frequent social contestation, as revealed by the research of Boulton (2019) and Armentor (2017), among others. It is a rheumatological syndrome, of obscure etiology, whose clinical presentation is composed of physical pain - musculoskeletal and diffuse - of non-inflammatory origin, associated with a set of other nonspecific physical and psychological symptoms (Häuser \& Fitzcharles, 2018).
Adding to this, fibromyalgia does not cause deformities, so it is considered as an "invisible disease."

Social contestation is capable of exacerbating the psychological suffering directly caused by fibromyalgia, as well as hindering access to appropriate treatments (Boulton, 2019). Moreover, it should be highlighted that, in recent years, qualitative research - alluding explicitly or not to the term "experiences" - attests that falling ill with fibromyalgia is challenging on several levels, as in many women it is accompanied by insecurities, afflictions, fears, and losses. In addition, it elicits anger, frustration, resentment, and sadness, as well as strains interpersonal relationships as a whole and impairs the continuation of previously habitual household and work activities (Ashe, Furness, Taylor, Haywood-Small, \& Lawson, 2017; Juuso, Skar, Olsson, \& Soderberg, 2011; Oliveira et al., 2019). None of these studies, however, involved recourse to the concept of collective imaginary in its psychoanalytic sense.

On the other hand, the integrative literature review conducted by Rosa, Lima, Peres, and Santos (2019) showed that the qualitative scientific production regarding the collective imaginary as defined from contemporary psychoanalysis already reaches a plurality of phenomena, experienced personally or not by the social group researched and offers valuable insights for its elucidation. And it is worth remembering that the various treatments currently indicated for fibromyalgia have advanced little in recent decades. Moreover, because they are merely symptomatic, they tend to generate unsatisfactory outcomes, which make evident the relevance of research that contemplates the experiences of falling ill by the syndrome from new perspectives, with original conceptual tools. Thus, this study aimed at investigating the collective imaginary about fibromyalgia in women affected by the syndrome.

\section{Method}

This is a qualitative study based on the psychoanalytic investigative method as conceived by the Brazilian psychoanalyst Fabio Herrmann. According to the author, the psychoanalytic investigative method is broken down into technical movements described later in this study, in the topic related to data analysis. However, it is worth anticipating that these technical movements are amenable to use in research on the social psyche and are not restricted to data collected in a conventional treatment apparatus (Herrmann, 2017). This premise, although problematized in formulations that controversially tie psychoanalysis to research concerned with exploring the individual psyche by examining material presented by patients in traditional analytic sessions, provides an important methodological support to qualitative scientific production concerning the collective imaginary in its psychoanalytic sense.

The studies of Gallo-Belluzzo et al. (2017) and Rosa et al. (2021) are examples of this, insofar as they do not make use of psychoanalysis only for the configuration of 
a theoretical reference framework from which the object of study is defined, but as a set of structured procedures for the generation of scientific knowledge. In addition, according to Hermann (2017) it is important to stress that the psychoanalytic investigative method should not be confused with the psychoanalytic therapeutic method, although there are similarities arising from the fact that both value interpretive processes. In any case, the psychoanalytic investigative method enables data collection procedures that, as such, may prove beneficial to the participants as they require from the researcher an empathic and welcoming posture towards the psychic contents mobilized.

\section{Participants}

A total of 18 women with fibromyalgia, aged between 35 and 63 years, whose time since the confirmation of the diagnosis ranged from seven months to 19 years, as shown in Table 1, participated in this study. Most of the participants were married and were professionally active, occupying positions that require a low level of expertise or that require only manual skills, also according to Table 1 . The exclusion criteria were: (a) presence of sensory or cognitive deficit identified or suspected - capable of substantially impairing verbal communication, (b) comorbidity with diseases that offer direct risk to life, and (c) diagnosis of fibromyalgia established less than six months ago. This last exclusion criterion was applied to define, with certainty as to the temporal parameter, the chronicity of the participants' clinical presentation and, as a consequence, to give some homogeneity to the sample regarding this fundamental aspect. Finally, it should be noted that the participants were a convenience sample, since they were recruited from a specialized non-governmental organization (NGO), selected by the ease of access by the researcher.

Table 1

Characterization of the participants by age, time of diagnosis, current occupation and marital status

\begin{tabular}{cc}
\hline Participant & Characteristic \\
\hline Andressa & 49 years old, diagnosed 11 years ago, general services assistant, married \\
Bernadete & 50 years old, diagnosed 19 years ago, homemaker, married \\
Carla & 47 years old, diagnosed six years ago, cashier, divorced \\
Diana & 54 years old, diagnosed 15 years ago, general service assistant, widowed \\
Eduarda & 46 years old, diagnosed three years ago, teacher, married \\
Francisca & 59 years old, diagnosed ten years ago, homemaker, married \\
Gláucia & 63 years old, diagnosed three years ago, homemaker, married \\
Heloísa & 60 years old, diagnosed ten years ago, retired, married \\
Inês & 35 years old, diagnosed 12 years ago, craftswoman, married \\
Júlia & 49 years old, diagnosed one year ago, receptionist, single \\
Kátia & 55 years old, diagnosed seven months ago, saleswoman, married \\
Luciana & 36 years old, diagnosed two years ago, saleswoman, married \\
Marisa & 53 years old, diagnosed ten years ago, homemaker, widowed \\
Núbia & 47 years old, diagnosed four years ago, nutrition assistant, married \\
Paloma & 45 years old, diagnosed seven years ago, warehouse assistant, married \\
Rosângela & 51 years old, diagnosed nine years ago, retired, divorced \\
Samara & 45 years old, diagnosed five years ago, saleswoman, married \\
Telma & 52 years old, diagnosed eight years ago, unemployed, married \\
\hline
\end{tabular}

Note. The names are fictitious.

\section{Instruments}

Drawing-Story with Theme Procedure. Data collection was conducted through group interviews guided by the Drawing-Story with Theme Procedure. This expedient, according to Rosa et al. (2019), is the most widely used in research on the collective imaginary in its psychoanalytic sense. It is worth clarifying that this procedure was developed by the Brazilian psychoanalyst Tania Maria José Aiello-Vaisberg through a modification of the DrawingStory Procedure, which, in turn, was created by the Brazilian psychoanalyst Walter Trinca. Both procedures are dialogic mediators of a graphic-verbal nature, as they conjugate expressive-motor and apperceptive-dynamic processes configuring a playful inter-human encounter with the participants. But the Drawing-Story with Theme Procedure differs because it contemplates, more specifically, imaginative productions about a certain phenomenon circumscribed by the researcher (Aiello-Vaisberg \& Ambrosio, 2013).

The activity proposed in the scope of group interviews guided by the Drawing-Story with Theme Procedure consists, basically, in asking the participants to draw a picture on the theme defined by the researcher, to elaborate a story about the drawing and to create a title for the story. It is worth noting 
that this dialogic mediator facilitates the composition of a transitional scenario conducive to obtaining research material impregnated with psychic contents, including non-conscious ones (Aiello-Vaisberg \& Ambrosio, 2013). This feature highlights the epistemological affinity of the Drawing-Story with Theme Procedure in relation to the psychoanalytic investigative method, which seeks to move away from the untenable abstraction of the human world resulting from the undue adherence to the ideals of maximum neutrality and objectivity advocated by positivism (Herrmann, 2017)).

\section{Procedure}

Data collection. A list with the names and telephone numbers of women with fibromyalgia who attended their services was obtained from the NGO. The researcher communicated by phone with most of them to disclose the study and identify those who could be considered eligible for participation. A day and time were scheduled for data collection with the women who agreed to participate. The list provided by the institution comprised 34 women, of whom five were not contacted and four could not be located, even after several attempts. Thus, the researcher communicated by telephone with 25 women, of whom four declined the invitation alleging unavailability of time and three accepted but did not attend data collection. None of these 25 women met the exclusion criteria mentioned.

The researcher did not get to contact all the women with fibromyalgia who attended the institution because the sample closure was determined by the saturation criterion, not by the exhaustion criterion. Consequently, the capture of new participants, as recommended by Fontanella, Ricas and Turato (2008), was interrupted when the researcher's evaluation identified a certain redundancy in the data. According to the authors, the saturation criterion was used to obtain a subset of people who possess the attributes defined as essential to achieve the aims of the research, so that it stands out as a useful mechanism of scientific validation. Turato (2013) states that to preserve these attributes, the researcher who develops qualitative research in the health field should, whenever possible, conduct data collection at the place where participants receive health care. And this guideline was observed in this study.

In total, four group interviews were carried out, and as there was no repetition of participants, the number of women who attended each one varied from six to three, due to their availability. The group interviews took place in a reserved room at the headquarters of the NGO, were audio recorded, lasted around one hour and 35 minutes, and were divided into three basic stages. In the first stage, participants seated arranged in a circle were asked by the researcher to introduce themselves by stating their name, age, time since the diagnosis, occupational situation, and marital status. The researcher took note of this information to adequately position himself in relation to the participants. The Drawing-Story with Theme Procedure was employed in the second stage. The participants were then asked to draw "a woman with fibromyalgia," then write a story about the drawing, and create a title for it, using what had been previously provided to each one: a black pencil, a sheet of paper and a clipboard.

In the third stage the participants were asked by the researcher to share their productions with the group, and as they did so, the researcher requested additional information in order to encourage new associations. In addition, the researcher stimulated the debate, opening space for comments and reflections. During the second stage of the group interview some participants said they didn't know how to draw, but were informed that the task did not require artistic skill and quickly agreed to perform it. Others, after producing their drawings, mentioned that they felt some discomfort in their arms or hands. The researcher then asked that their stories be presented verbally, so that a possible worsening of the discomfort could be avoided.

To conclude the description of the data collection procedure, it is important to clarify that the researcher in charge was neither a member of the staff of the NGO, nor did he know any of the participants. However, he had already conducted previous research at the institution, which is why acculturation and adaptation activities were considered unnecessary specifically for the purposes of this study. Indeed, the researcher has extensive experience in developing collective interviews guided by the Drawing-Story with Theme Procedure and introduced himself to the participants as a psychologist and university professor. It should be highlighted that no gender-related indicators of embarrassment were observed during data collection. On the contrary, in general, the participants felt at ease to talk about various topics, including intimate ones.

Data analysis. The corpus of this study was composed of the transcription - verbatim and in full - of all the verbalizations conveyed by the participants during the group interviews and complementarily by the drawings arising from the use of the Drawing-Story with Theme Procedure. This material was examined in order to capture the fields of meaning that sustain the collective imaginary of the participants about fibromyalgia. In psychoanalytic terms, fields of meaning correspond to a variety of psychological environments that, in specific moments, are inhabited by individuals and social groups that typically do not realize it on a conscious level. (Manna et al., 2018). Thus, fields of meaning shape each of the relationships that take place in the human world and decisively influence the way existential events are processed (Aiello-Vaisberg \& Ambrosio, 2013; Gallo-Belluzzo et al., 2017).

In this study, the capture of fields of meaning - as in the research signed by Gallo-Belluzzo et al. (2017) and Rosa et al. (2021), among others - was guided by the technical movements recommended by Herrmann (2001) for the operationalization of the psychoanalytic investigative method. These technical movements, following the author, are based on a double attitude defined by the oscillation from a receptive passivity to an active receptivity aiming at the proposition of interpretations. At the expense of this double attitude, the researcher undertook successive 
non-selective readings of the corpus to, in the words of Herrmann (2017), promote the unveiling of "marginal" meanings, representative of the logic that governs the unconscious. Subsequently, the interpretations proposed by the researcher were discussed and refined during meetings of his respective research group, taking into account that group interlocution favors the demarcation of new meanings of the corpus (Gallo-Belluzzo et al., 2017). Moreover, the use of this strategy represents a mechanism for scientific validation.

\section{Ethical Considerations}

This study was approved by the Research Ethics Committee of the Universidade Federal de Uberlândia, CAAE number 86402218.7.0000.5152. It is necessary to stress that all ethical recommendations pertinent to research with human beings were respected, according to the legislation in force in Brazil. Thus, the participants signed a Free and Informed Consent Form after information on the procedures that would be conducted in data collection and also the disclosure of results, especially in order to preserve the identity of each one of them. The participants were also informed that they could request to the researcher an individual focal psychological assistance to manage psychic contents mobilized by the data collection. However, none of them requested so, perhaps because many of them were already receiving psychological counseling at the NGO itself, in public health services, or in clinics affiliated with health insurance plans.

\section{Results}

The data analysis allowed the capture of two fields of meaning, which were named as follows: "A body that hurts" and "An extra pain." The first field of meaning derives from data interpreted by the researcher as an indication that many participants, as an unfolding of fibromyalgia, often see themselves, in a non-conscious way, reduced to a painful body. Their collective imaginary is marked by the belief that the syndrome, especially due to the physical pain that is typical of it, caused significant damage in different spheres of life, preventing them from continuing to perform - at least as they did before - the roles that defined and identified them as persons. In this scenario, the participants tend to experience frustration and anger, which in some cases leads to a feeling of uselessness that increases the psychological suffering resulting more directly from physical pain. Excerpts 1, 2, and 3 are emblematic of this:

1. We feel useless, because sometimes there is something you want to do and you can't do it [due to physical pain]. Your physical condition does not allow you to do that [...] This makes us have a stress, a nervousness, we get out of control (Participant Carla) 2. I was one of those who never took a dipyrone.
I was super active, I did everything, carried everything, took everything and had nothing. When I felt a pain, like this, it was a tickle, right? [...] And now I can't [due to physical pain]. And I get angry about it (Participant Luciana)

3. I was a manicurist and hairdresser [...] I danced, I did street dancing [...] But the daily life of a woman with fibromyalgia is very difficult $[\ldots]$ In this, our psychological becomes very bad, because you want to do that [daily activities], but your body cannot handle it, your body does not respond [due to physical pain] (Participant Inês)

The drawing made by participant Andressa corroborates this interpretation, as it shows a woman in tears due to the accumulated work in the domestic environment, symbolized by piles of dishes to wash and clothes to iron. It is worth noting that dark circles on the body of the drawn woman, as the participant herself clarified, represent her sore spots. She also emphasized that before fibromyalgia she was a "normal person" as she was in charge of a wide range of domestic and professional tasks. And these tasks, it seems, structured her personal identity. Similarly, several participants talked about negative transformations caused by the syndrome and pointed to it as a "turning point," especially because the physical pain had made them incapacitated and dependent.

Excerpt 4 is exemplary in this regard: "A person that has this problem [fibromyalgia] can no longer be productive, can no longer do what was done before" (Participant Núbia). Excerpt 5 is similar, but differs by emphasizing the displeasure caused by dependence, specifically regarding the maintenance of the domestic environment, generated by physical limitations arising from the syndrome: "The others [family members] have to do things [domestic activities] for me, but I like to do it and I do it well, I do like it. It's very bad that." (Participant Diana). And excerpt 6 refers to an even more critical situation, because the psychological suffering resulting directly from physical pain seems to be enhanced by helplessness: "I drew a bed and a person with fibromyalgia, you know? [...] She's trying to get up, but with a lot of pain and crying. And, at that moment, there was no one in the house to help $[\ldots]$ and that's pretty sad" (Participant Júlia).

The field of meaning "An extra pain" gravitates around the verification that, in the collective imaginary of participants, the invisibility of fibromyalgia leads directly to misunderstanding and stigmatization. After all, the participants, with few exceptions, claimed that they were often treated by people in general with skepticism about the veracity of their symptoms. This would occur, for them, because their symptoms are not evident, as illustrated in excerpt 7: "Fibromyalgia is like this: nobody believes in the disease. Nobody believes you have it. Only the person knows. There is no test that verifies this type of disease, right? [...] 'What is the test that shows it?' [...] There is no test that shows" (Participant Rosângela). Excerpt 8, in turn, highlights that skepticism can manifest itself with remarkable disdain: "Many people think it's not a disease, 
but that fibromyalgia is invented by the person. They think you're just flipping out" (Participant Heloísa). Therefore, in addition to the psychological suffering caused by the syndrome per se, the participants experience psychological suffering resulting from social contestation.

The excerpt 9 is particularly representative of this: "People do not believe that you have fibromyalgia. It is an additional pain, because you have no support from anyone, not even a family member" (Participant Eduarda). However, what seems more interesting in this excerpt is that this psychological suffering was described as a pain that is added to the physical pain caused by fibromyalgia, and it is verified in excerpt 10: "We go to talk about pain, and people turn their beaks. [...] This hurts us a lot $[\ldots]$ it hurts more than the pain we feel. It hurts a lot more" (Participant Bernadete). In other words: addressing the researcher, these participants spoke about the psychological suffering they experience, semantically bringing it closer to the bodily symptom that tend to be a priority target of delegitimization for those composing the clinical presentation of the syndrome.

For some participants, as a consequence, the psychological suffering triggered by social contestation - the "additional pain," that "hurts a lot more," to which excerpts 9 and 10 allude - would be particularly susceptible to devaluation by people in general. For this reason, it would also be more intense. That said, it is important to explain that the word "extra," in the title of the second field of meaning, was used as an adjective both to designate something beyond what is expected and to express the idea of great intensity, which refers to its use as a prefix. It is also important to clarify that the psychological suffering seems to be verbally exteriorized only in exceptional circumstances, because several participants stated that they strive to make fibromyalgia invisible, due to the discredit with which they assume they will be faced. Excerpt 11 is an example of this: "I avoid complaining. So, people think it's okay, but it's not [...] And then nobody feels sorry for us" (Participant Francisca).

The same applies to excerpt 12, in which there is more indignation: "[Fibromyalgia] is not something you create in your mind. I've heard this too much. [...] So I may be in pain, but I stay quiet in my space, I don't say anything to avoid hearing what I don't want to hear" (Participant Samara). However, a part of them hinted that - voluntarily or involuntarily - they exteriorize in a non-verbal way, through their facial expressions, for example, the psychological suffering resulting from social contestation. The fact that participant Paloma referred to fibromyalgia as "the disease of the frowned face" provides support for this line of reasoning. And it is pertinent to mention, still regarding the second field of meaning, that some of the participants who said they tend to be silent suggested that they feel pressured to perform certain tasks that, when assumed, generate an annoyance that leads to the aggravation of physical pain, as suggested by the excerpt 13: "Everything you do that you were forced to do will cause you even more pain" (Participant Telma).

\section{Discussion}

In general, the results concerning the field of meaning "A body that hurts" corroborate the findings of previous research that emphasize the disruptive potential of falling ill with fibromyalgia. One of these studies found that many Brazilian women affected by the syndrome consider their daily lives stressful and painful, mainly because of the functional limitations imposed by physical pain, as well experience hopeless about the risks of unfavorable evolution of the syndrome (Oliveira et al., 2019). Moreover, all participants in the study developed in England by Brown (2018) showed, to a greater or lesser extent, difficulties in adapting to the new reality brought about by fibromyalgia. Thus, they were forced to review their life projects, and most of them resigned when they realized that the chronicity typical of the syndrome could make some of their main dreams impossible.

Also with regard to the first field of meaning, it should be noted that a study developed in the United Kingdom aimed at exploring the experience of living with the syndrome highlighted that, in many cases, the loss of physical abilities unfolds in the loss of professional identity (Ashe et al., 2017). It occurs that fibromyalgia, by impairing the continuity of previous work activities, forces the transition from an active to a passive life, which tends to generate marked negative repercussions in psychological, social, and financial terms. Our study adds that the resonances of fibromyalgia on personal identity eventually culminate in certain dehumanization, as many participants, according to the field of meaning "A body that hurts" no longer recognize the body they inhabit as the place of inscription of their own subjectivity. Soon, they started, unconsciously, to see it no longer as a "body-person," to use the expression forged by Ávila (2012), but as something purely biological, devoid of the symbolic traces previously decisive for the demarcation of their individualities.

It should be highlighted that the point of view to be developed with this interpretation does not subscribe to Cartesian-inspired conceptions according to which to an individual - or, more precisely, to his or her body - would be applicable the model of intelligibility concerning the elements of the natural world or the physical universe in general. On the contrary, it is intend to highlight the fact that, as psychoanalysis has shown since its early days, the body has objective and subjective dimensions. However, as Costa (2004) warned with the support of contemporary psychoanalytic theses, the experience of the body as which is most singular in each human being depends on psychological conditions partly provided by the individual's ability to use his or her bodily performance to establish communication channels between the internal and external realities. And, in a significant portion of the participants in our study, it seems that this capacity is quite compromised, especially by physical pain, which helps to explain the fragility of the bond that seems to unite them to their own bodies. 
The results regarding the field of meaning "An extra pain," in terms of their predominantly manifest significations, illustrate the social contestation of fibromyalgia and are compatible with those obtained in international research. After all, Boulton (2019) pointed out that many Canadian and English women affected by the syndrome feel discredited, not infrequently by health professionals, due to the lack of empirical traces of organic changes capable of validating their symptoms. Armentor (2017), in turn, revealed that American women often evaluate that, as an effect of the invisibility of fibromyalgia, they receive insufficient social support to cope with it and, as a consequence, find themselves isolated. In addition, Juuso et al. (2011) found that, in response to social contestation, Swedish women tend to hide the symptoms of the syndrome, because they consider that, after illness, they are no longer taken seriously by the people with whom they live.

Based on this reasoning, to the predominantly latent significations of the second field of meaning can be attributed greater novelty, especially because they denote that some participants experience the psychological suffering produced by the stigmatization of fibromyalgia as a kind of pain. This seems to testify a concomitantly affective and sensory unpleasant experience. It must be clarified that what is intended to be underlined with this interpretation is that it would be inadequate to assume that the referred psychological suffering, although described in certain excerpts precisely as an "additional pain", would be consciously channeled to the bodily sphere, or that there would be conscience of an eventual movement, even if involuntary, in this direction. In reality, these excerpts apparently reflect stylistic particularities of the participants' narratives, suggesting that it is at an unconscious level that social contestation are experienced by them on both the psychic and physical planes.

This possibility becomes more concrete under the aegis of a fundamental psychoanalytic assumption, according to which the formations of the unconscious - including those related to language - take on guises that, despite varying substantially from one subject to another due to their psychological characteristics, are greatly influenced by social and cultural determinants (Val, Modena, Campos, \& Gama, 2017). In other words, perhaps some participants have qualified as a kind of pain what they feel when misunderstood because they used a terminology that is familiar to them, since physical pain is the main symptom of fibromyalgia. And this finding can also be understood by taking into account that since its emergence psychoanalysis has emphasized that body articulates the material and the immaterial or, put another way, the organic and the representational, as Fortes, Winograd, and Perelson (2018) observed.

This line of reasoning culminates in the demarcation of convergences between psychological suffering arising from social contestation, as reported by the participants, and a state of intense emotional disturbance called "mental pain" by the Portuguese psychoanalyst Manuela Fleming. For the author, it is an amalgam of helplessness and affliction that, due to intrapsychic and/or intersubjective restrictions, is hardly named and clearly communicated by those who experience it (Fleming, 2003). Finally, another interpretation may be sketched in order to relate some of the excerpts gathered in the field of meaning "An extra pain" to a possible non-conscious propensity to the bodily expression of feelings that escape psychic elaboration. This interpretation is supported by the findings of Béjar (2017), because, for the author, the contemporary psychoanalytic clinic attests that many women with fibromyalgia unconsciously tend to produce physical symptoms rather than psychological symptoms when they reach the limit of their representational capacities.

Therefore, the participants' collective imaginary about fibromyalgia seems to lead to paradoxical experiences. The first field of meaning signals that many participants often non-consciously see themselves reduced to a painful organism, and from this, an erasure of certain points of intersection between mind and body is inferred. In contrast, the second field of meaning shows that some of them describe the psychological suffering triggered by the social contestation as a pain in addition to the physical pain caused by the syndrome, which illustrates, through certain confusion between sensations and affections, the mobility of the existing boundaries between biological and psychological functioning. In fact, the understanding of this psychological suffering as a mental pain, as previously proposed based on Fleming's (2003) formulations, reinforces this argument, since it denounces an emotional disturbance that defies the capacity of verbal expression, thus tending to be exteriorized in a non-verbal manner or from the use of a linguistic code "invented by the body," following the words of the author.

In summary, the first field of meaning indicates that for many participants fibromyalgia caused the abandonment of a series of roles that defined them and profoundly deteriorated the cohesion of the personal identity of each one of them. Thus, some participants no longer feel to be the same persons they were before or, in certain cases, unconsciously no longer regard themselves as persons at all. And the second field of meaning highlights that delegitimization amounts to a secondary burden for several participants, as it generates psychological suffering described as a kind of pain. Then, it is possible to conclude that this study has made possible an incursion into the collective imaginary about fibromyalgia in women affected by the syndrome, reaching the proposed aim. Therefore, it seems reasonable to propose that the interpretations formulated regarding the corpus illuminate, from a new angle, some non-conscious bases of the experiences associated with the illness.

The use of the concept of collective imaginary evidenced that the multiple connections established between the particular and the contextual, especially in a non-conscious manner, originate ways of thinking, feeling, and acting towards falling ill with fibromyalgia. Additionally, our study, like many others, reaffirms the heuristic value of the psychoanalytic investigative method and, by doing so, 
offers a relevant contribution. This is because, as already mentioned, the psychoanalytic investigative method is still the target of objections - controversial ones, it is worth reinforcing - when used in favor of exploring the social psyche beyond the traditional analytic sessions. It is suggested that future studies, based on a similar theoreticalmethodological configuration, focus on the collective imaginary of professionals who are dedicated to health care for women with fibromyalgia, in view of the results concerning the second field of meaning. However, it must be pointed out that this study has limitations. One of them is related to the fact that each participant attended only one group interview. Future research may evaluate the costeffectiveness of conducting a second group interview with the same participants.

In any case, the findings provided by this study have practical implications, since, according to Ávila (2012), treatments that do not address the plurality of facets of illness experiences typically prove to be unproductive, if not iatrogenic. More specifically, it is recommended that the results reported here be taken into account in the health care offered by multidisciplinary teams to women with fibromyalgia and translated into the valorization of relational technologies in order to mitigate the negative impact of delegitimization and social contestation in their experiences. And it is indicated that the psychologist should take the lead in this movement, considering that biomedical knowledge, historically, has fostered technicist and nosocentric interventions. Finally, the development of awareness campaigns about fibromyalgia is recommended, so that the prejudices that still surround it can be overcome and both physical pain and mental pain related to the syndrome come to be recognized as health problems.

\section{Referências}

Aiello-Vaisberg, T. M. J., \& Ambrosio, F. F. (2013). Rabiscando Desenhos-Estórias com Tema: Pesquisa psicanalítica de imaginários coletivos [Scribbling Thematic Drawing-Stories: Psychoanalytic research of collective imaginaries]. In W. Trinca (Org.), Procedimento de Desenhos-Estórias: Formas derivadas, desenvolvimentos e expansões [Drawing-Stories Procedure: Derived forms, developments and expansions] (pp. 277-302). São Paulo, SP: Vetor.

Armentor, J. L. (2017). Living with a contested, stigmatized illness: Experiences of managing relationships among women with fibromyalgia. Qualitative Health Research, 27(4), 462-473. doi:10.1177/1049732315620160

Ashe, S. C., Furness, P. J., Taylor, S. J., Haywood-Small, S., \& Lawson, K. (2017). A qualitative exploration of the experiences of living with and being treated for fibromyalgia. Health Psychology Open, 4(2), 2055102917724336. doi:10.1177/2055102917724336
Ávila, L. A. (2012). Body, subjectivity and psychosomatics. Tempo Psicanalítico, 44(1), 51-69. Retrieved from http://pepsic.bvsalud.org/scielo.php? script=sci arttext\&pid=S0101-48382012000100004

Béjar, V. R. (2017). Dor corporal e dor psíquica: Discursos do corpo [Body pain and psychic pain: Discourses of the body]. In V. R. Béjar (Org.), Dor psíquica, dor corporal: Uma abordagem multidisciplinar [Psychic pain, body pain: A multidisciplinary approach] (pp. 121-146). São Paulo, SP: Blucher.

Boulton, T. (2019). Nothing and everything: Fibromyalgia as a diagnosis of exclusion and inclusion. Qualitative Health Research, 29(6), 809-819. doi:10.1177/1049732318804509

Brown, N. (2018). Exploring the lived experience of fibromyalgia using creative data collection methods. Cogent Social Sciences, 4(1), 1447759. doi:10.1080/ 23311886.2018.1447759

Canesqui, A. M. (2018). Legitimidade e não legitimidade das experiências dos sofrimentos e adoecimentos de longa [Legitimacy and non-legitimacy of experiences of long-term suffering and illness]. Ciência \& Saúde Coletiva, 23(2), 409-416. doi:10.1590/141381232018232.14732017

Costa, J. F. (2004). O vestígio e a aura: Corpo e consumismo na moral do espetáculo [The vestige and the aura: Body and consumerism in the moral of the spetacle]. Rio de Janeiro, RJ: Garamond.

Gallo-Belluzzo, S. R., Ferreira-Teixeira, M. C., \& Aiello-Vaisberg, T. M. J. (2017). The imaginary of Brazilian adolescents in relation to university entrance exams: A psychoanalytic study. Paidéia (Ribeirão Preto), 27(Suppl. 1), 404-412. doi:10.1590/1982432727 s1201705

Fleming, M. (2003). Dor sem nome: Pensar o sofrimento [Nameless pain: A reflection on suffering]. Porto, Portugal: Afrontamento.

Fontanella, B. J. B., Ricas, J., \& Turato, E. R. (2008). Amostragem por saturação em pesquisas qualitativas em saúde: Contribuições teóricas [Saturation sampling in qualitative health research: Theoretical contributions]. Cadernos de Saúde Pública, 24(1), 17-27. doi:10.1590/ S0102-311X2008000100003

Fortes, I., Winograd, M., \& Perelson, S. (2018). Some considerations about the body in the current psychoanalytic scenario. Psicologia USP, 29(2), 277-284. doi:10.1590/0103-656420170154

Häuser, W., \& Fitzcharles, M. A. (2018). Facts and myths pertaining to fibromyalgia. Dialogues in Clinical Neuroscience, 20(1), 53-62. doi:10.31887/ DCNS.2018.20.1/whauser 
Herrmann, F. (2001). Introdução à Teoria dos Campos [Introduction to the Theory of Fields]. São Paulo, SP: Casa do Psicólogo.

Herrmann, F. (2017). Sobre os fundamentos da Psicanálise: Quatro cursos e um preâmbulo [On the foundations of Psychoanalysis: Four courses and a preamble]. São Paulo, SP: Blucher.

Juuso, P., Skar, L., Olsson, M., \& Soderberg, S. (2011). Living with a double burden: Meanings of pain for women with fibromyalgia. International Journal of Qualitative Studies in Health and Well-Being, 6(3), 7184. doi:10.3402/qhw.v6i3.7184

Manna, R. E., Leite, J. C. A., \& Aiello-Vaisberg, T. M. J. (2018). Collective imaginary of elderly people participating in the Protection and Defense Network of the Elderly Person. Saúde e Sociedade, 27(4), 987-996. doi:10.1590/s0104-12902018180888

Minayo, M. C. S. (2012). Qualitative analysis: Theory, steps and reliability. Ciência \& Saúde Coletiva, 17(3), 621-626. doi:10.1590/S1413-81232012000300007

Oliveira, J. P. R., Berardinelli, L. M. M., Cavaliere, M. L. A., Rosa, R. C. A., Costa, L. P., \& Barbosa, J. S. O. (2019). The routines of women with fibromyalgia and an interdisciplinary challenge to promote selfcare. Revista Gaúcha de Enfermagem, 40, e20180411. doi:10.1590/1983-1447.2019.20180411

Rosa, D. C. J., Lima, D. M., Miranda, L., \& Peres, R. S. (2021). "Problem-patient": Collective imaginary of nurses about the user diagnosed with schizophrenia. Physis: Revista de Saúde Coletiva, 31(1), e310108. doi:10.1590/S0103-73312021310108

Rosa, D. C. J., Lima, D. M., Peres, R. S., \& Santos, M. A. (2019). The concept of collective imaginary in its psychoanalytic sense: An integrative review. Psicologia Clínica, 31(3), 577-595. doi:10.33208/PC19805438v0031n03A09

Trinca, W. (2013). Procedimento de Desenhos-Estórias: Formas derivadas, desenvolvimentos e expansões [Drawing-Stories Procedure: Derived forms, developments and expansions]. São Paulo, SP: Vetor.

Turato, E. R. (2013). Tratado de metodologia da pesquisa clínico-qualitativa: Construção teórico-epistemológica, discussão comparada e aplicações nas áreas de saúde $e$ humanas [Treatise on clinical-qualitative research methodology: Theoretical-epistemological construction, comparative discussion and application in the health and humanities areas] (6th ed.). Petrópolis, RJ: Vozes.

Val, A. C., Modena, C. M., Campos, R. T. O., \& Gama, C. A. P. (2017). Psychoanalysis and public health: Approaches and possibilities of contributions. Physis: Revista de Saúde Coletiva, 27(4), 1287-1307. doi:10.1590/s010373312017000400022
Rodrigo Sanches Peres is a Professor of the Universidade Federal de Uberlândia, Uberlândia-MG, Brazil.

\section{Authors' Contribution:}

The author was responsible for study conception and design, data analysis and interpretation, manuscript revision and approval of the final version. The author assumes public responsibility for the content of this manuscript.

Associate Editor:

Marina Simões Flório Ferreira Bertagnoli

Received: Apr. 05, 2021

1st Revision: Jun. 24, 2021

Approved: Aug. 23, 2021

How to cite this article:

Peres, R. S. (2021). Experiences of falling ill with fibromyalgia: An incursion into the collective imaginary of women. Paidéia (Ribeirão Preto), 31, e3140. doi:https://doi.org/10.1590/1982-4327e3140 